\title{
Particle Selection in Suspension-Feeding Bivalves
}

\author{
Thomas Kiørboe and Flemming Møhlenberg
}

Marine Biological Laboratory, Strandpromenaden, DK-3000 Helsingor, Denmark

\begin{abstract}
Particle selection was studied in 10 species of suspension-feeding bivalves by comparing the proportion of algae in the pseudofaeces with that in the surrounding water. All species examined exhibited particle selection, but with different efficiencies. Spisula subtruncata was most efficient, followed, in decreasing order of efficiency, by Corbula gibba, Mytilus edulis (from Wadden Sea), Acanthocardia echinata, Aequipecten opercularis, Musculus niger, Crassostrea gigas, Mya arenaria, Cerastoderma edule, Mytilus edulis (from Øresund), and Arctica islandica. Selection efficiency correlated with the size of the labial palps. Particles rejected as pseudofaeces were embedded in mucus, whereas ingested particles were always in free suspension in $M$. edulis. Apparently, then, different particles have different probabilities of being trapped in mucus, and thus rejected as pseudofaeces. The properties which determine this probability are unknown.
\end{abstract}

\section{INTRODUCTION}

Earlier authors generally believed, mainly based on observational and morphological evidence, that suspension-feeding bivalves possess the ability of particle selection (see reviews by Owen, 1966; Purchon, 1968; Foster-Smith, 1978). The currently accepted view is, however, that suspension-feeding bivalves are nonselective (e. g. Foster-Smith, 1975a, b, 1978; Bayne et al., 1976; Winter, 1978).

In neritic waters, the concentration of particulate inorganic matter normally exceeds the concentration of particulate organic matter by about one order of magnitude. Above a threshold concentration of particulate matter (about $1 \mathrm{mg}$ Tot. dried matter $\mathrm{l}^{-1}$ in Mytilus edulis, Kiorboe et al., 1980), an increasing amount of material retained by the bivalve gill is rejected as pseudofaeces of potential food value. The effect of suspended inorganic material is therefore potentially to 'dilute' the particulate organic matter of the food suspension, and thus to decrease the amount of organic matter ingested. As natural particle concentrations in estuaries and other neritic waters are generally in the range $5-20 \mathrm{mg} \mathrm{l}^{-1}$ (e. g. Oviatt and Nixon, 1975), well above the threshold concentration for pseudofaeces production in $M$. edulis, the question of particle selection is obviously important to considerations of energetics in neritic bivalves.

Most laboratory studies on energetics of suspensionfeeding bivalves have been made with pure suspen- sions of algae as food source. However, in view of the quite different particle composition of natural sea water, attention has recently been drawn to the effect of suspended inorganic matter (e.g. Winter, 1976; Widdows et al., 1979; Griffiths, 1980; Kiørboe et al., 1980, 1981; Newell and Bayne, 1980; Tsuchiya, 1980; Vahl, 1980). Most of these authors have assumed that the bivalves concerned - i. e. Mytilus edulis L., Cerastoderma edulis (L.), Choromytilus meridionalis ( $\mathrm{Kr}$.) Chlamys islandica (O. F. Müller) - were non-selective. This assumption has either been made explicitly with reference to the work of Foster-Smith (1975a, b, 1978), or implicitly by using the 'Conovor-ratio' (Conovor, 1966) for estimating assimilation efficiency. The application of this ratio assumes non-selective feeding.

We have found, however, that the species most commonly used in the above studies, Mytilus edulis, exhibits particle selection (Kiørboe et al., 1980). When fed a mixture of algae and suspended bottom material above the threshold concentration for pseudofaeces production, comparison of the proportion of algae in pseudofaeces and particle suspension showed that $2 / 3$ of the algae had been removed from the material rejected as pseudofaeces. Thus, the potential food diluting effect of suspended inorganic particles is counteracted by particle selection in $M$. edulis.

In this study we examine and quantify the efficiency of particle selection in 10 species of suspension-feeding bivalves. Earlier authors have pointed to the labial palps as the site of particle selection (e. g. Owen, 1966; 
Purchon, 1968), and indicated that the size of the palps is an adaptation to the particle concentrations encountered by the bivalves in their natural habitats (e. $\mathrm{g}$. Nelson, 1960; Ansell, 1961; Theisen, 1977). We have therefore compared the measured selection efficiencies with the size of the palps, both within and between species. Probably the strongest argument against particle selection is the widely reported observation that particles retained by the gills are embedded into mucus (e. g. MacGinitie, 1941; Foster-Smith, 1975b, 1978). It is hard to envisage any mechanism of particle selection, when the particles are bound in mucus strings. To check these observations we have therefore examined the esophagus content of undisturbed, actively filtering Mytilus edulis, to decide whether particles ingested are embedded in mucus or are in free suspension.

\section{MATERIAL AND METHODS}

Experiments were carried out between November 1979 and October 1980. Specimens of Mytilus edulis L., Musculus niger (Gray), Aequipecten opercularis (L.). Arctica islandica (L.), Acanthocardia echinata (L.), Cerastoderma edule (L.), Spisula subtruncata (da Costa), Mya arenaria (L.) and Corbula gibba (Olivi) were collected in the Oresund. Specimens of Crassostrea gigas (Thunberg) were obtained from an oyster farm in the Little Belt. Additional specimens of $M$. edulis were collected in the Danish Wadden Sea. The bivalves were kept in running sea water from laboratory tanks (ca $30 \% \mathrm{~S} ; 9^{\circ}$ to $17^{\circ} \mathrm{C}$ ) until used for experiments.

\section{Measurements of Selection Efficiency}

The bivalves were fed a mixture of the unicellular al.gae Phaeodactylum tricornutum $\left(10-30 \times 10^{3}\right.$ cells $\mathrm{ml}^{-1}$ ) and suspended bottom material (10-20 $\mathrm{mg} \mathrm{l}^{-1}$ ), prepared as described by Kiørboe et al. (1980). Particle selection was studied by comparing the relative chl aconcentrations ( $\mu \mathrm{g} \mathrm{chl}$ a/mg dry $\mathrm{wt}$ ) in the particle suspension offered and the pseudofaeces rejected by the actively filtering bivalves. Without selection the particle composition of the pseudofaeces becomes similar to that of the inhalant water. A lower relative concentration of $\mathrm{chl}$ a in the pseudofaeces, on the other hand, shows that particles retained by the gill are selectively sorted, and algae are ingested in preference to other particles. These considerations assume that all particles in the water passing the gill are retained, and that the dry weight of mucus in the pseudofaeces is negligible. Comparison of the reten- tion efficiencies given by Mohlenberg and Risgard (1978) for most of the species with the particle size distribution of the particle suspension, shows the first to be true. Furthermore, the particle retention efficiency of Mytilus edulis is not influenced by high particle concentrations (Kiorboe et al., 1980). No measurements of the dry weight of the mucus rejected with the pseudofaeces are available. However, in specimens which exhibit positive growth, the dry weight of mucus must be considerable less than the dry weight of material ingested. At a concentration of $20 \mathrm{mg} \mathrm{l}^{-1}$ of suspended bottom material in addition to algae, young M. edulis grow at a high rate (Kiørboe et al., 1981), and the dry weight of material ingested is equal to about $3 \%$ of the dry weight of the pseudofaeces (including mucus) rejected (Kiørboe et al., 1980). The ratio of the relative chl a-concentration in the particle suspension and the pseudofaeces was used as a measure of the efficiency of particle selection.

For experiments infaunal bivalves were allowed to burrow in crystallization dishes filled with washed sand with a particle diameter of about $0.2 \mathrm{~mm}$. One individual was placed in each dish, except for smallsized species and specimens (Spisula subtruncata, Corbula gibba, Arctica islandica) where several individuals were grouped. Epifaunal species were placed in Petri dishes without sediment. 1-4 dishes with animals were placed in the experimental aquarium (25 l), and algae and suspended bottom material were added. Particles were kept in suspension by a magnetic stirrer. Throughout the experimental period $(1 / 2-2$ h) the concentration was kept approximately constant by adding extra algae and suspended bottom material in the same proportion. Samples of the particle suspension were taken repeatedly or continuously. At the end of an experiment pseudofaeces produced by the bivalves were carefully collected with a pipette. Faeces and sand grains that might have been pipetted up with the pseudofaeces were removed under a dissecting microscope. The pseudofaeces were then resuspended in about $100 \mathrm{ml}$ filtered sea water. One half of this was analyzed for particulate material ( $\mathrm{mg} \mathrm{l}^{-1}$ ), and the other for chl a $\left(\mu \mathrm{g} \mathrm{l}^{-1}\right)$ by means of an Aminco Fluoro- Colorimeter, as decribed by Strickland and Parsons (1968).

\section{Measurements of Palp Size}

Individuals used for measurements were anesthetized with an isotonous solution of $\mathrm{MgCl}_{2}$ before dissection to relax the muscular palps. The outline of the palps was drawn under appropriate magnification with the aid of a drawing apparatus. The area of one palp was calculated by weighing the cuttings. To compare palp areas between bivalves of different sizes and 
species, palp area has to be related to some appropriate measure of the the size of the bivalve. We have chosen to express palp size relative to particle clearance, since clearance is a measure of the potential amount of material to be treated by the palps.

\section{Measurements of Clearance}

To measure clearance in Corbula gibba, 25 individuals were allowed to establish themselves in 4 small dishes with sand. The dishes were then placed in a crystallisation dish, and water was added to a volume of 1.2 1. Algae (Dunaliella marina) were added (about $5000 \mathrm{ml}^{-1}$ ) and kept suspended by a magnetic stirrer. When all individuals had opened fully, the exponential decrease in algal concentration was followed during about $1 \mathrm{~h}$ by a Coulter Counter Model B, and the clearance calculated.

Clearance of Mytilus edulis from the Wadden Sea and Crassostrea gigas were measured by the method of Møhlenberg and Riisgård (1979). Individuals were placed in sea water with a concentration of $10-20 \times$ $10^{3}$ Phaeodactylum tricornutum cells $\mathrm{ml}^{-1}$, and after they had opened maximally, in- and exhalant water was collected qualitatively by glass tubes placed immediately above the in- and exhalant apertures, respectively. Algal concentrations in in- and exhalant water were measured, and clearance calculated. Clearance of the remaining species were obtained from Møhlenberg and Riisgård (1979), who used bivalves from the same localities.

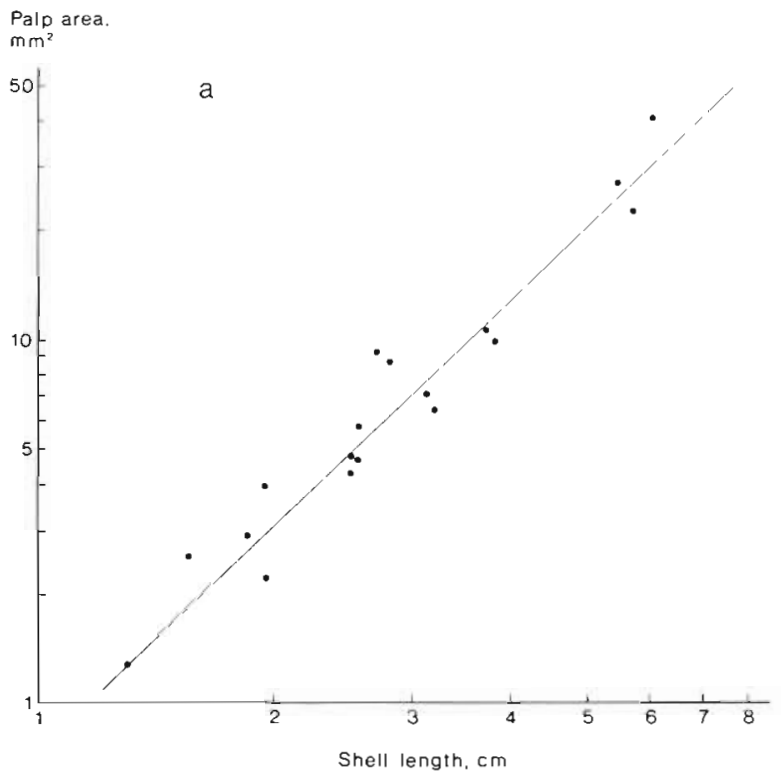

\section{Palp Size Index}

Both palp area and clearance were assumed to be proportional to the square of the length of the bivalve. Thus, for each species, regressions of the form:

$$
\mathrm{Y}=a \mathrm{~L}^{2}
$$

( $\mathrm{Y}=$ palp area in $\mathrm{mm}^{2}$ or clearance in $\mathrm{ml} \mathrm{min}^{-1} ; \mathrm{L}=$ shell length in $\mathrm{cm}$ ) were fitted to the data after logarithmic transformation. Estimates of a are thus estimates of palp area (one palp) or clearance of a $1 \mathrm{~cm}$ bivalve of the species considered.

We have assumed an exponent of 2, as the exponent for many of the species could not be properly estimated due to few observations on too small a size range. That this assumption holds true at least for Mytilus edulis from the Øresund is illustrated in Fig. 1.

\section{Observations on Esophagus Content}

Mytilus edulis were fed Phaeodactylum tricornutum cells, both at concentrations above and below the threshold for pseudofaeces production. Actively feeding individuals were quickly opened, and under the dissection microscope a sample of esophagus content was taken by a fine pipette within $30 \mathrm{~s}$. The sample was investigated under the microscope. Water was drawn under the cover glass, to see whether the algae moved relative to one another (in free suspension), or not (i. e. embedded in mucus).

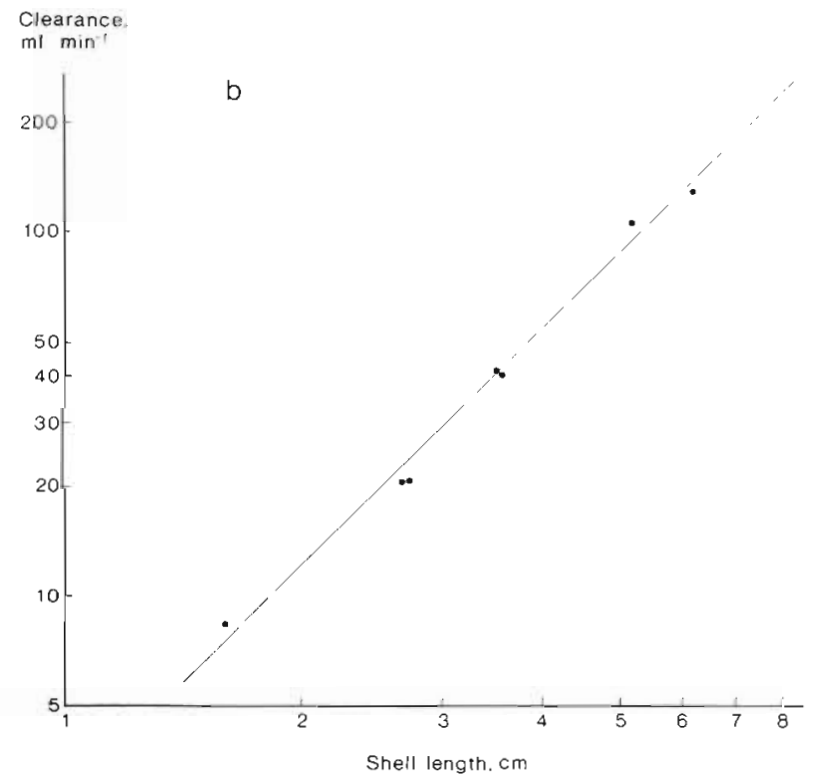

Fig. 1. Mytilus edulis. Logarithmic plots of (a) palp size $\left(\mathrm{mm}^{2}\right)$ and (b) clearance $\left(\mathrm{ml} \mathrm{min}^{-1}\right)$ versus shell length ( $\mathrm{cm}$ ). The estimated regressions are (a) $\ln ($ palp size) $=5.06+2.07 \ln ($ length),$r=0.98$, and (b) $\ln ($ clearance) $=-3.90+2.14 \ln ($ length)

$$
r=0.99
$$


Table 1. Selection efficiency and palp size index for 10 species of bivalves. Clearance and palp area are estimated from length regressions, and are given for individuals of $1 \mathrm{~cm}$ shell length (estimates \pm SD). SD for clearance and palp area estimates are assymetric due to logarithmic transformation. SD for Corbula gibba clearance cannot be estimated, since clearance was measured on a group of individuals. $n=$ number of measurements

\begin{tabular}{|c|c|c|c|c|c|c|c|c|c|}
\hline Species & \multicolumn{2}{|c|}{$\begin{array}{l}\text { Clearance } \\
\left(\mathrm{ml} \mathrm{min}^{-1}\right)\end{array}$} & $\mathrm{n}$ & \multicolumn{2}{|c|}{$\begin{array}{c}\text { Palp area } \\
\quad\left(\mathrm{mm}^{2}\right)\end{array}$} & n & $\begin{array}{l}\text { Palp-size } \\
\text { index }\end{array}$ & $\begin{array}{l}\text { Selection } \\
\text { efficiency }\end{array}$ & $n$ \\
\hline Mytilus edulis (The Sound) & 3.36 & $\begin{array}{l}+0.16 \\
-0.15\end{array}$ & 7 & 0.79 & $\begin{array}{l}+0.04 \\
-0.04\end{array}$ & 19 & 0.24 & $2.9 \pm 1.0$ & 20 \\
\hline Mytilus edulis (Wadden Sea) & 2.75 & $\begin{array}{l}+0.17 \\
-0.16\end{array}$ & 8 & 1.84 & $\begin{array}{l}+0.11 \\
-0.10\end{array}$ & 11 & 0.67 & $9.1 \pm 1.9$ & 8 \\
\hline Musculus niger & 0.49 & $\begin{array}{l}+0.00 \\
-0.00\end{array}$ & 1 & 0.88 & $\begin{array}{l}+0.02 \\
-0.02\end{array}$ & 3 & 1.8 & $5.1 \pm 2.7$ & 15 \\
\hline Crassostrea gigas & 3.84 & $\begin{array}{l}+0.32 \\
-0.30\end{array}$ & 10 & 1.00 & $\begin{array}{l}+0.06 \\
-0.06\end{array}$ & 6 & 0.26 & $4.5 \pm 2.2$ & 31 \\
\hline Aequipecten opercularis & 5.61 & $\begin{array}{l}+0.18 \\
-0.18\end{array}$ & 3 & 1.12 & $\begin{array}{l}+0.09 \\
-0.08\end{array}$ & 10 & 0.20 & $5.4 \pm 2.0$ & 22 \\
\hline Arctica islandica & 3.79 & $\begin{array}{l}+0.39 \\
-0.36\end{array}$ & 7 & 0.65 & $\begin{array}{l}+0.05 \\
-0.05\end{array}$ & 7 & 0.17 & $2.3 \pm 0.7$ & 9 \\
\hline Acanthocardia echinata & 4.90 & $\begin{array}{l}+0.13 \\
-0.13\end{array}$ & 7 & 2.70 & $\begin{array}{l}+0.14 \\
-0.13\end{array}$ & 13 & 0.55 & $5.9 \pm 3.4$ & 15 \\
\hline Cerastoderma edule & 6.89 & $\begin{array}{l}+0.57 \\
-0.52\end{array}$ & 10 & 1.33 & $\begin{array}{l}+0.22 \\
-0.19\end{array}$ & 7 & 0.19 & $4.3 \pm 1.7$ & 20 \\
\hline Spisula subtruncata & 2.90 & $\begin{array}{l}+0.40 \\
-0.35\end{array}$ & 2 & 4.70 & $\begin{array}{l}+0.40 \\
-0.37\end{array}$ & 8 & 1.62 & $15.8 \pm 4.3$ & 8 \\
\hline Mya arenaria & 1.85 & $\begin{array}{l}+0.32 \\
-0.27\end{array}$ & 3 & 0.92 & $\begin{array}{l}+0.15 \\
-0.13\end{array}$ & 6 & 0.50 & $4.4 \pm 2.0$ & 20 \\
\hline Corbula gibba & 1.41 & & 2 & 0.93 & $\begin{array}{l}+0.31 \\
-0.24\end{array}$ & 13 & 0.66 & $9.3 \pm 1.8$ & 23 \\
\hline
\end{tabular}

Selection efficiency

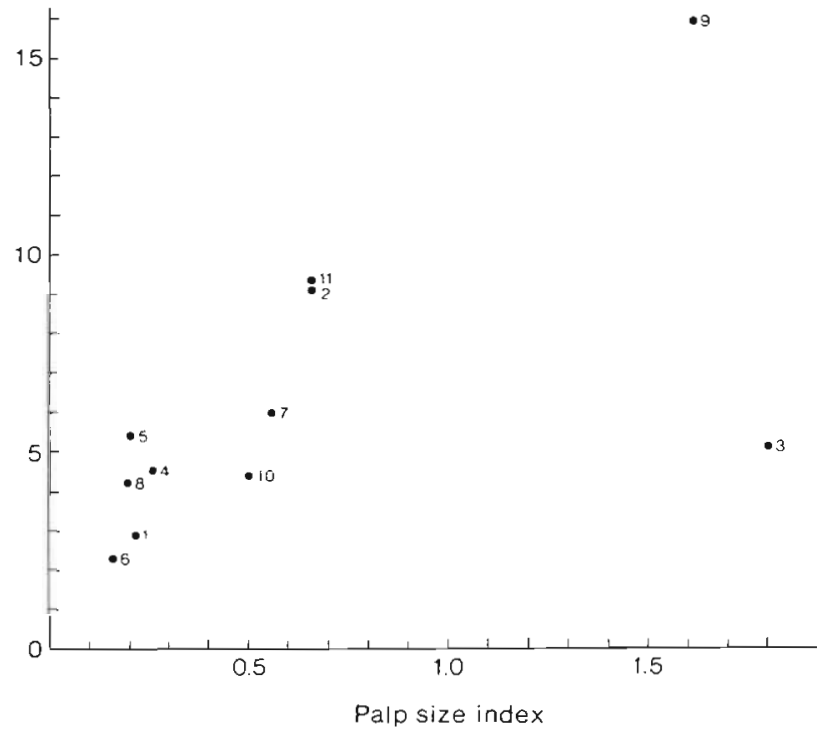

Fig. 2. Plots of selection efficiency (relative Chl a concentration in inhalant water/relative Chl a concentration in pseudofaeces) against palp-size index (palp area relative to clearance). Numbers refer to species. 1: Mytilus edulis (Øresund); 2: $M$. edulis (Wadden Sea); 3: Musculus niger; 4 : Crassostrea gigas; 5: Aequipecten opercularis; 6: Arctica islandica; 7: Acanthocardia echinata; 8: Cerastoderma edule; 9: Spisula subtruncata; 10: Mya arenaria; 11: Corbula gibba

\section{RESULTS}

\section{Efficiency of Particle Selection}

All 10 species studied exhibited the ability of particle selection (Table 1). The efficiencies differed significantly between species, and correlated positively with the palp size index (Fig. 2). One species, Musculus niger, deviated from this picture. However, the palp size index is based on a single clearance measurement, which is much lower than in all other species on a weight specific basis (Møhlenberg and Riisgård, 1979). The experimental temperature $\left(10^{\circ} \mathrm{C}\right)$ may have been too high for this northern boreal/ panarctic species. Excluding $M$. niger from analysis, the correlation between selection efficiency and palp size index is highly significant (Spearman rank correlation coefficient, $r_{s}=0.88, p<0.1 \%$ ). If $M$. niger is included in the analysis, the correlation is still significant $\left(\mathrm{r}_{\mathrm{s}}=0.75, \mathrm{p}<1 \%\right)$.

\section{Observations on Esophagus Content}

Neither when fed below nor above the threshold concentration for pseudofaeces production, were parti- 
cles in the esophagus of Mytilus edulis embedded in mucus, but were freely suspended.

\section{DISCUSSION}

Particle selection is an obvious advantage to suspension feeders in a turbid environment. The larger labial palps and the more efficient particle selection of Wadden Sea mussels as compared to mussels from Øresund seems to be an adaptation to the very turbid waters of the Wadden Sea. While the maximum concentration of particulate matter recorded in bottom-near water of Øresund is about $10 \mathrm{mg} \mathrm{l^{-1 }}$ (W. Nicolaisen and $\mathrm{H}$. Christensen, pers. comm.), concentrations up to several hundreds of $\mathrm{mg} \mathrm{l}^{-1}$ have been reported from the Wadden Sea (Gry, 1942).

The concentration of particulate matter in bottomnear water is related to the sediment type in shallow water, due to resuspension of bottom material. Young and Rhoads (1971) found higher turbidity above soft bottoms than above sand bottoms in Cap Cod Bay, Massachusetts, USA. It is therefore to be expected that species inhabiting soft and/or mixed bottoms will exhibit large labial palps and be efficient particle selectors in comparison to species inhabiting sand bottoms. Within closely related species or between different populations of the same species (Venerupis, Crassostrea/Ostrea, Mytilus edulis) correlations between turbidity and palp size have been reported accordingly (Ansell, 1961; Nelson, 1960; Theisen, 1977). In a comparison of the species of the present study, however, no such clear correlation emerge between palp size or selection efficiency on the one hand, and sediment characteristics of the species' habitats on the other. For example, the species with the largest palp size index, Spisula subtruncata, typically inhabits sandy bottoms, whereas Arctica islandica, with the smallest palp size index and selection efficiency, is mainly found on soft bottoms, even though the two species may occur together. Whereas S. subtruncata is a very fast-growing species (attaining a size of $8-10 \mathrm{~mm}$ during the first 4-5 mo in Øresund), with a short life span (mainly annual in Øresund), A. islandica is extremely slowgrowing and long-living (e. g. Thompson et al., 1980). The very different selection efficiencies of these two species must be considered together with their different growth rates. Thus, differences in palp size and selection efficiency have to be interpreted in context with the overall ecology of the species, together with considerations of particle composition and concentration in their natural habitats. It is not possible at present to carry this more complex analysis very far for most of the species.

There is a good deal of scatter in the plot of the selection efficiency against palp size index (Fig. 2). This is of course partly due to the great variances of the efficiency estimates (Table 1). Moreover, palp s iz e is a simplified expression of the morphology of the palp. Considerable variation in the structure of the palps extists between species, e.g. in number of plica, ciliation, and in the contact between palps and gills (e.g. Allen, 1958; Forster-Smith, 1975b, 1978). Therefore, a perfect relationship between palp size and its function would not be expected.

While the positive correlation between palp size and selection efficiency indicates that the palps take part in the selection of particles, the mechanism involved is unknown. Any hypothesis of the mechanism must, however, take the following observations into consideration: (1) Particle selection is possible only when pseudofaeces are produced. At particle concentrations below the pseudofaeces threshold, all particles retained by the gill are ingested indiscriminately. (2) Particles ingested are in free suspension, irrespective of particle concentration, while particles rejected as pseudofaeces are embedded in mucus. These observations show that different particles have different probabilities of being caught in mucus and thus of being rejected as pseudofaeces. To proceed any further in revealing the mechanism of particle selection, it is necessary to know the criterion by which particles are selected. As pointed out by Jørgensen (1981), water currents over gills and palps are characterized by very low Reynolds' numbers. Thus gravitational forces are insignificant. It is therefore unlikely that the specific gravity of particles is a criterion of selection. At present, we have no positive suggestions of the criterion supported by evidence.

Acknowledgements. Thanks are due to Professor C. Barker Jørgensen and Dr. K. W. Ockelmann for stimulating discussions and criticism of the manuscript, and to $H$. Noer for help with statistical analysis. The project was financed by the National Agency for protection of nature, monuments and sites.

\section{LITERATURE CITED}

Allen, J. A. (1958). On the basic form and adaptations to habitat in the Lucinacea (Eulamellibranchia). Phil. Trans R. Soc. (Ser B) 241: 421-484

Ansell, A. D. (1961). The functional morphology of the British species of Veneracea (Eulamellibranchia). J. mar, biol. Ass. U.K. 41: 489-515

Bayne, B. L., Thompson, R. J., Widdows, J. (1976). Physiology I. In: Bayne, B. L. (ed.) Marine mussels. Their ecology and physiology. Cambridge University Press, Cambridge, pp. 121-206

Conover, R. (1966). Assimilation of organic matter by zooplankton. Limnol. Oceanogr. 11: 338-354

Foster-Smith, R. L. (1975a). The effect of concentration of suspension and inert material on the assimilation of algae by three bivalves. J. mar. biol. Ass. U. K. 55: 411-418 
Foster-Smith, R. L. (1975b). The role of mucus in the mechanism of feeding in three filter-feeding bivalves. Proc. malac. Soc. Lond. 41.571-588

Foster-Smith, R. L. (1978). The function of the pallial organs of bivalves in controlling ingestion. J. moll. Stud. 44: 83-99.

Griffiths, R. J. (1980). Natural food availability and assimilation in the bivalve Choromytilus meridionalis. Mar. Ecol. Prog. Ser 3: 151-156

Gry, H. (1942). Das Wattenmeer bei Skallingen. Physiographisch-biologische Untersuchung eines dänischen Tidengebietes. No. 1. Quantitative Untersuchungen über den Sinkstofftransport durch Gezeitenströmungen. Folia Geogr Danica 2: 1-138

Jørgensen, C. B. (1981). A hydromechanical model for particle retention in Mytilus edulis and other ciliary suspension feeders. Mar Biol. 61: 277-282

Kiørboe, T., Møhlenberg, F., Nøhr, O. (1980). Feeding, particle selection and carbon absorption in Mytilus edulis in different mixtures of algae and resuspended bottom material. Ophelia 19: 193-205

Kiørboe, T., Møhlenberg, F., Nøhr, O. (1981). Effect of suspended bottom material on growth and energetics in Mytilus edulis. Mar. Biol. 61: 283-288

MacGinitie, G. E. (1941). On the method of feeding by four pelecypods. Biol. Bull. mar. biol. Lab., Woods Hole 80: $18-25$

Møhlenberg, F., Riisgård, H. U. (1978). Efficiency of particle retention in 13 species of suspension feeding bivalves. Ophelia 17: 239-246

Møhlenberg, F., Riisgård, H. U. (1979). Filtration rate, using a new indirect technique, in thirteen species of suspensionfeeding bivalves. Mar. Biol. 54: 143-148

Nelson, T C. (1960). The feeding mechanism of the oyster. II On the gills and palps of Ostrea edulis, Crassostrea virginica and C. angulata. J. Morph. 107: 163-191

Newell, R. I. E., Bayne, B. L. (1980). Seasonal changes in the physiology, reproductive condition and carbohydrate content of the cockle Cardium.$(=$ Cerastoderma) edule (Bivalvia: Cardiidae). Mar. Biol. 56: 11-19

Oviatt, C. A., Nixon, S. W. (1975). Sediment resuspension and deposition in Narraganset Bay. Estuar. coast. mar. Sci. 3: $201-217$
Owen, G. (1966). Feeding In: Wilbur, K. M., Younge, C. M. (eds) Physiology ot mollusca, Vol 2. Academic Press, New York, pp. 1-15

Purchon, R. D. (1968). The biology of the mollusca, Pergamon Press, Oxford

Riisgård, H. U., Møhlenberg, F. (1979). An improved automatic recording apparatus for determining the filtration rate of Mytilus edulis as a function of size and algal concentration. Mar Biol. 52: 61-67

Strickland, J. D. H., Parsons, T R. (1968). A practical handbook of seawater analysis, Fish. Res. Bd Can., Ottawa

Theisen, B. F. (1977). Feeding rate of Mytilus edulis L. (Bivalvia) from different parts of Danish waters in water of different turbidity. Ophelia 16: 221-232

Thompson, I., Jones, D. S., Dreibelbis, D. (1980). Annual internal growth banding and life history of the ocean Quahog Arctica islandica (Mollusca: Bivalvia). Mar. Biol. 57: $25-34$

Tsuchiya, M. (1980). Biodeposit production by the mussle Mytilus edulis L. on rocky shores. J. exp. mar. Biol. Ecol. 47: 203-222

Vahl, O. (1980). Seasonal variations in seston and in the growth rate of the Iceland scallop Chlamys islandica (O. F. Müller) from Balsfjord, $70^{\circ} \mathrm{N}$. J. exp. mar. Biol. Ecol. 48: 195-204

Widdows, J., Fieth, P., Worral, C. M. (1979). Relationship between seston, available food and feeding activity in the common mussel Mytilus edulis. Mar. Biol. 50: 195-207

Winter, J. E. (1976). Feeding experiments with Mytilus edulis L. at small laboratory scale. II. The influence of suspended silt in addition to algal suspensions on growth. In: Persone, G., Jaspers, E. (eds) Proceedings of 10 th European Marine Biology Symposium, Ostend, Belgium, Sept. 17-23, 1975. Universa Press, Wetteren, pp. 583-600

Winter, J. E. (1978). A review on the knowledge of suspension-feeding in lamellibranchiate bivalves, with special reference to artificial aquaculture systems. Aquaculture 13: $1-33$

Young, D. K., Rhoads, D. C. (1971). Animal-sediment relations in Cape Cod Bay, Massachusetts. I. A transect study. Mar. Biol. 11. 242-254. 